\title{
Article
}

\section{The Optic Strut-CBCT Pneumatization Pattern and Prevalence}

\author{
Casian Teodor Sicoe (D), Cătălina Bichir * and Mugurel Constantin Rusu (D)
}

check for

updates

Citation: Sicoe, C.T.; Bichir, C.; Rusu, M.C. The Optic Strut-CBCT Pneumatization Pattern and Prevalence. Appl. Sci. 2021, 11, 5797. https://doi.org/10.3390/app11135797

Academic Editor: Jin Seo Park

Received: 25 May 2021

Accepted: 16 June 2021

Published: 22 June 2021

Publisher's Note: MDPI stays neutral with regard to jurisdictional claims in published maps and institutional affiliations.

Copyright: (c) 2021 by the authors. Licensee MDPI, Basel, Switzerland. This article is an open access article distributed under the terms and conditions of the Creative Commons Attribution (CC BY) license (https:/ / creativecommons.org/licenses/by/ $4.0 /)$.
Division of Anatomy, Faculty of Dental Medicine, "Carol Davila" University of Medicine and Pharmacy, RO-020021 Bucharest, Romania; teodorcasian.t.sicoe@stud.umfcd.ro (C.T.S.); mugurel.rusu@umfcd.ro (M.C.R.) * Correspondence: catalina.bichir@drd.umfcd.ro

\begin{abstract}
Background: The optic strut (OS) is a critical landmark for clinoid and paraclinoid surgical interventions. To our knowledge, the current literature only mentioned the OS as a possibility for a lesser sphenoidal wing (LSW) pneumatization path, without a proper study of the pneumatization patterns and prevalence within this structure. Thus, our aim was to fill in the missing information. (2) Methods: A retrospective study on 80 cone beam computed tomography (CBCT) files was conducted to assess the prevalence and the origins of pneumatization within the OS. (3) Results: The pneumatization patterns of the OS were: $56.25 \%$ from the sphenoid sinus, $1.25 \%$ from the posterior ethmoid air cells (PEAC), and 10\% from Onodi cells (ONC). Simultaneous pneumatization of unique origin within the lesser sphenoidal wing (LSW) was found in $26.25 \%$ from the sphenoid sinus, $1.25 \%$ from PEAC, and 5\% from ONC. Communication between both LSW roots through pneumatization was found in $6.25 \%$ of the files. (4) Conclusions: A careful radiological examination should precede clinical diagnosis and surgical interventions in the paraclinoid area to evaluate postoperative surgical risks and possible diffusion patterns for infection. Additionally, pneumatization within the OS alters its morphological features and thus, its utility as a landmark.
\end{abstract}

Keywords: optic strut; sphenoid bone; anterior clinoid process; Onodi cell; computed tomography

\section{Introduction}

The inferior root of the sphenoid's lesser wing (LSW) is also known as the optic strut (OS). The OS is a bony projection that forms the inferolateral wall of the optic canal (OC), separating it from the superior orbital fissure (SOF) and all its content.

The OS is an important landmark when it comes to surgery within the sellar and parasellar regions [1]. ICA aneurysms can be classified as intradural and extradural, based on the morphological relationship between the insertion of the proximal dural ring and the inferior margin of the OS [2]. The OS is also an important element in the differential diagnosis. Cares and Bakay stated that "no other portion of the optic canal is as important in characterizing an optic lesion as the strut" [3]. Signs such as OS erosion and enlargement of the SOF are "pathognomonic for an infraclinoid aneurysm"; deformation of the OS or concentric enlargement of the OC can be associated with optic tract tumors; and erosion of OS in association with other canal walls may suggest a nonvascular issue such as mucocele or tuberculosis of the sphenoid, orbital or nasopharyngeal malignancies or pituitary gland tumors [3]. Deformities of the OS have been encountered in carotid-cavernous fistulas, suprasellar cholestheatomas, and syndromes such as Down and Edwards [1].

Air cells within the OS are in the proximity of several anatomical structures, such as: the optic nerve $(\mathrm{ON})$ and ophthalmic artery in the $\mathrm{OC}$, the cavernous sinus, the internal carotid artery (ICA), and the nerve fibers that pass the SOF (oculomotor nerve, trochlear nerve, branches of ophthalmic nerve and abducens nerve) [4]. Pneumatization sites within the body are frequently associated with pathways of diffusion for inflammatory and infectious pathologies or tumors [5].

The lack of a proper radiological evaluation of the OS during parasellar surgery may translate into intraoperative accidents or postoperative complications, such as rhinorrhea, 
visual function perturbation, intracranial bleeding, or pneumocephalus, all to the extent of a fatal outcome $[4,6]$.

Most studies examine the pneumatization within the LSW regarding the anterior clinoid process (ACP), mentioning the OS as a bridge for air cells to reach the ACP. To our knowledge, no study has been conducted strictly on OS pneumatization for prevalence or its source (via sphenoid sinus, ethmoid posterior cells, or Onodi air cells).

\section{Materials and Methods}

A retrospective study on 80 DICOM (Digital Imaging and Communications in Medicine) anonymous patient files ( 20 men and 60 women) was conducted. None of the patients presented skull deformities or signs of previous surgical interventions in the area of interest.

The subjects were positioned according to the manufacturer's instructions and had been scanned using an iCat CBCT machine (Imaging Sciences International (Hatfield, PA, USA)) with the settings: resolution-0.250, field of view-130, and image matrix size $-640 \times 640$. The $\mathrm{CT}$ data were analyzed using the iCatVision software and its related application 3DVR v5.0.0.3. The CBCT files were further exported as DICOM files, which were additionally analyzed with the Planmeca Romexis Viewer 3.5.0.R software (Planmeca, Helsinki, Finland) [7].

The presence of pneumatization within the OS was investigated bilaterally on all three planes, and classified according to the site of origin as Type 1-sphenoidal pneumatization, Type 2-ethmoidal pneumatization, Type 3-from an Onodi cell (ONC). Additional information, such as the presence of $\mathrm{ONC}$, the extension of the pneumatic tract to the ACP and sex, was also noted. The files were analyzed by two examiners.

The Microsoft Office Excel program was used for data analysis.

\section{Results}

\subsection{OS Pneumatization}

A total of $85 \mathrm{OS}(53.12 \%)$ were pneumatized. The prevalence of OS pneumatization within the total was $67.5 \%$ (45 female and 9 male patients), $42.6 \%$ (23 cases) of them being unilateral (Table 1) (Figures 1 and 2).

Table 1. Origin and prevalence of the pneumatization from the paranasal sinuses in optic strut. ONC—Onodi cell. $\mathrm{N}=85$ sides.

\begin{tabular}{ccc}
\hline \multirow{2}{*}{ Origin } & \multicolumn{2}{c}{ Patients } \\
\cline { 2 - 3 } & Unilateral & Bilateral \\
\hline Type 1-Sphenoid & $15(27.77 \%)$ & $30(55.55 \%)$ \\
Type 2-Ethmoid (non-ONC) & $1(1.85 \%)$ & 0 \\
Type 3-Ethmoid (ONC) & $7(12.96 \%)$ & $1(1.85 \%)$ \\
\hline
\end{tabular}

\subsection{ACP Pneumatization}

Unique pneumatization of the ACP through the OS was encountered in $8.75 \%$ of cases.

Simultaneous pneumatization of both LSW roots was noted in 31 cases $(38.75 \%)$ and 43 sides (26.87\%) (Table 2; Figure 3). This kind of extensive pneumatization was more frequent in the female group ( 22 cases, $71 \%$ ).

Five $(16.13 \%)$ out of the 31 cases with pneumatization of both LSW roots presented combined pneumatization. If, for the other cases, the origin came either from PEAC (non$\mathrm{ONC} / \mathrm{ONC}$ ) or the sphenoid sinus, in these 5 cases, the simultaneous pneumatization occurred from separated origins for each of the two (Figure 3). Two of these patients presented the ONC extending into the OS and the sphenoidal sinus within AR, and the other three cases presented ONC pneumatization extended within the AR and the sphenoidal sinus with a recess within the OS. 
Table 2. Origin and prevalence of the pneumatization from the paranasal sinuses in the optic strut (OS) and the anterior root (AR) of the lesser sphenoidal wing. ONC-Onodi cell. $\mathrm{N}=43$ sides.

\begin{tabular}{ccc}
\hline \multirow{2}{*}{ Origin } & \multicolumn{2}{c}{ Patients } \\
\cline { 2 - 3 } & Unilateral & Bilateral \\
\hline Sphenoid (non-ONC) & $10(32.25 \%)$ & $11(35.48 \%)$ \\
Ethmoid (non-ONC) & $1(3.22 \%)$ & 0 \\
Ethmoid (ONC) & $3(9.67 \%)$ & $1(3.22 \%)$ \\
Sphenoid (ONC) & $5(16.12 \%)$ & 0 \\
\hline
\end{tabular}

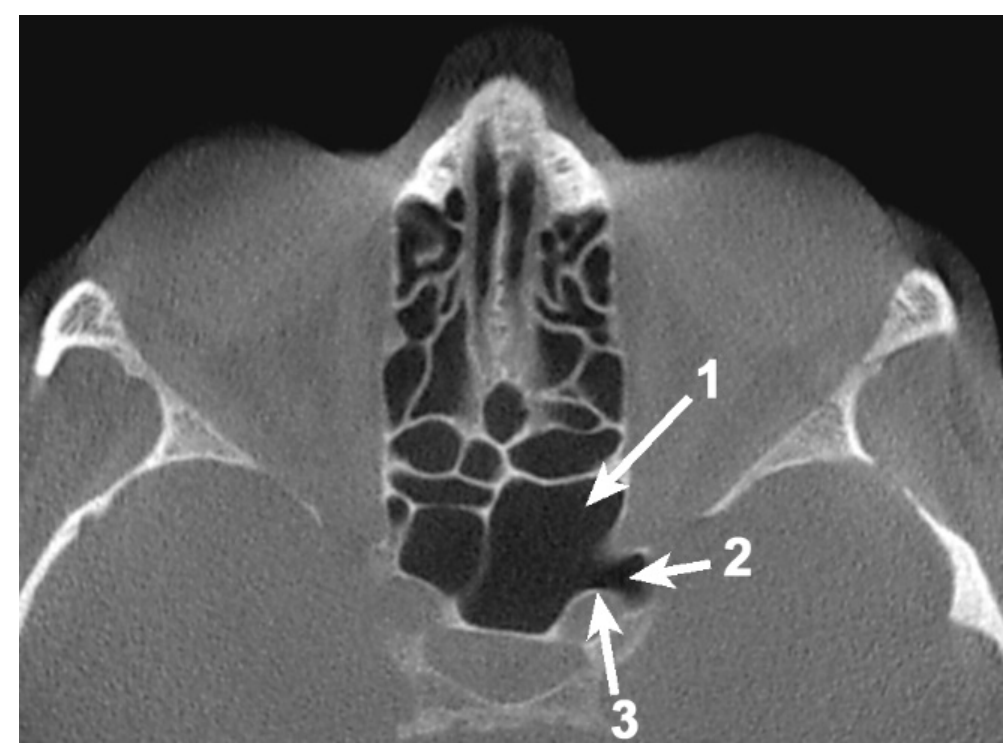

Figure 1. Axial CBCT slice at the level of the left anterior clinoid process (ACP), demonstrating the unilateral pneumatization of the ACP via the optic strut (OS) from the sphenoid sinus. 1. Sphenoid sinus; 2. Pneumatized ACP; 3. Pneumatized OS.

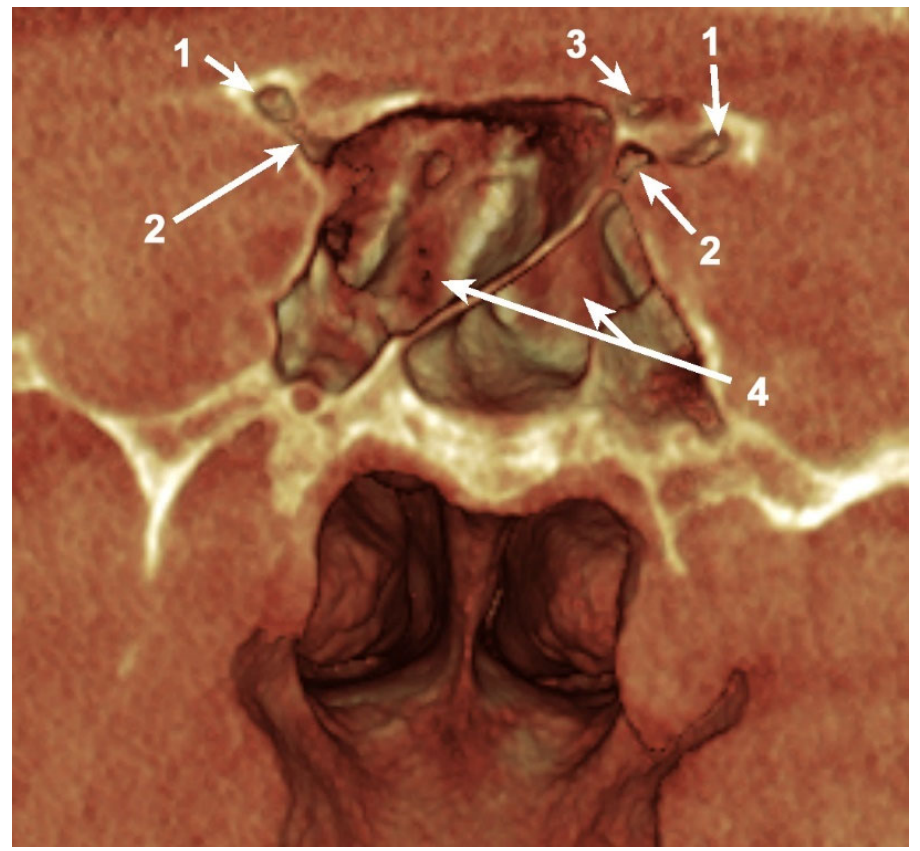

Figure 2. Coronal, bilateral three-dimensional volume rendering of the anterior clinoid process (ACP) and sphenoid sinus, posterior view. 1. Pneumatized ACP; 2. Pneumatized optic strut; 3 . Pneumatized anterior root; 4 . Sphenoid sinus. 


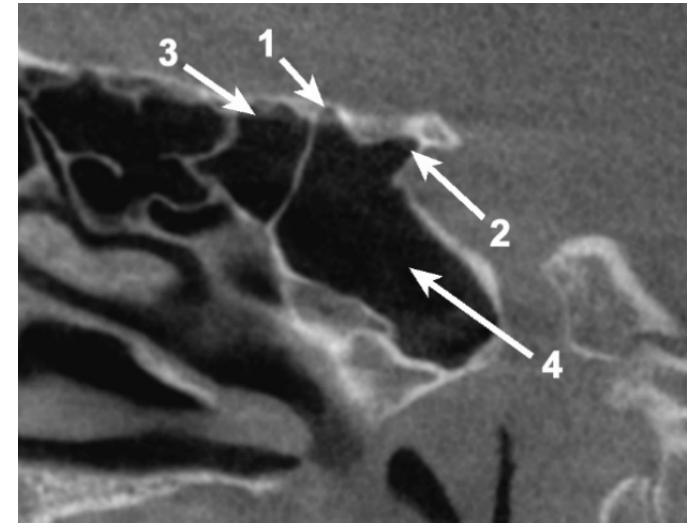

(a)

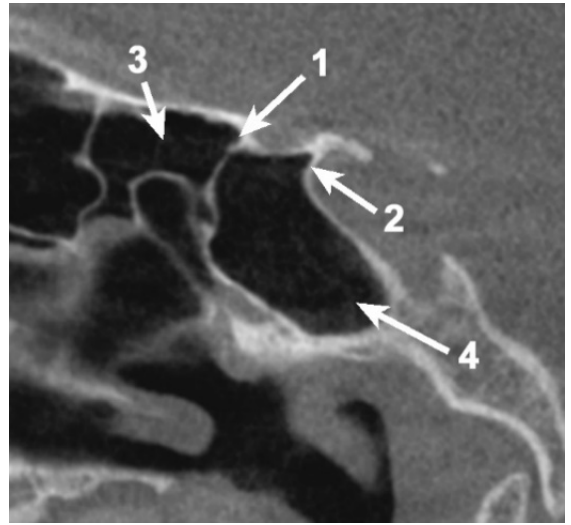

(b)

Figure 3. Bilateral sagittal CBCT reconstruction, demonstrating the pattern of pneumatization of both the optic strut (OS) and anterior root (AR). (a) Left side; (b) Right side: 1. Pneumatized AR; 2. Pneumatized OS; 3. Onodi cell; 4. Sphenoid sinus.

The ONCs were recorded on 23 sides (14.40\%). These corresponded to 15 cases, of which 4 were male $(26.66 \%)$ and 11 were female $(73.33 \%)$ patients. Eight patients $(53.33 \%)$ presented a bilateral symmetry of ONCs and seven patients $(46.66 \%)$ a one-sided ONC.

In 8 out of 15 cases $(53.33 \%)$, the ONC was the origin of pneumatization of the OS. Of these cases, two were male (25\%) and six were female (75\%). In seven cases (one male and six female patients), the ONC was the source of unilateral pneumatization within the OS. A case of a bilateral pneumatized OS from the ONCs was noticed in a male patient (Table 3).

Table 3. Origin and symmetry of the pneumatization from the paranasal sinuses within the optic strut. ONC-Onodi cell. $\mathrm{N}=54$ cases.

\begin{tabular}{cccc}
\hline \multirow{2}{*}{ Origin } & \multicolumn{3}{c}{ Patients } \\
\cline { 2 - 4 } & Unilateral Right & Unilateral Left & Bilateral \\
\hline $\begin{array}{c}\text { Type 1-Sphenoid } \\
\text { Type 2-Ethmoid } \\
\text { (non-ONC) }\end{array}$ & $6(11.11 \%)$ & $9(16.66 \%)$ & $30(55.55 \%)$ \\
$\begin{array}{c}\text { Type 3-Ethmoid } \\
\text { (ONC) }\end{array}$ & $1(1.85 \%)$ & 0 & 0 \\
\hline
\end{tabular}

In 54/80 cases (67.5\%), pneumatization within the OS could be identified (Figure 4 ). In eight cases ( $8.75 \%$ - six unilateral and two bilateral cases), the pneumatization of the sphenoid bone passed the OS, reaching the ACP.

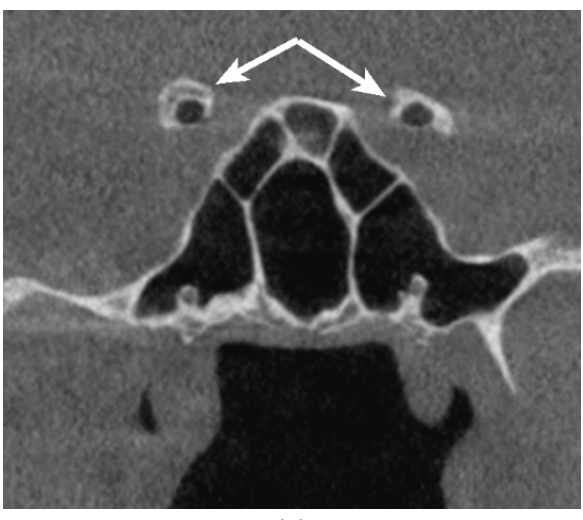

(a)

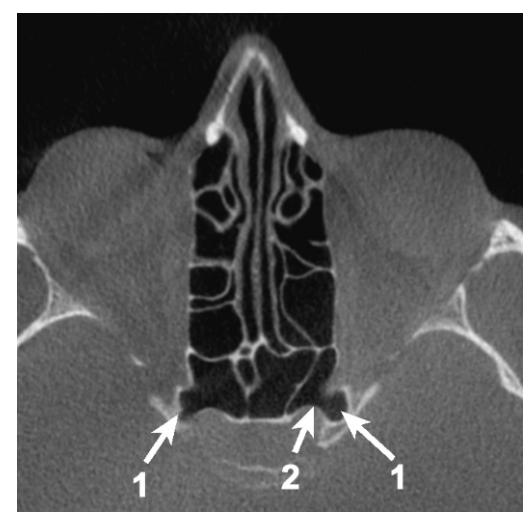

(b)

Figure 4. Bilateral sagittal CBCT reconstruction, demonstrating the pattern of pneumatization of both the optic strut and anterior root (AR) of the lesser sphenoidal wing. (a) Left side. (b) Right side: 1. Pneumatized AR; 2. Pneumatized OS; 3. Onodi cell; 4 . Sphenoid sinus. 


\section{Discussion}

The little bridge that is the OS is often examined in aid of important information during differential diagnosis [3] and is considered of critical value as a landmark in many surgical interventions [1].

Given the nature of the parasellar pathologies, it is clear that the morphological aspect of this structure is of great interest to otolaryngologists, neurosurgeons, and ophthalmologists. Treatment usually implies surgical access within the area and the OS is often used as a reference for the course of action and planning of the procedure as well as an intraoperative surgical guide [1].

Pneumatization within the sphenoid bone facilitates trans-sphenoidal access; air channels passing through the OS, and the ACP reduce the drilling time and ensure more controlled drilling of the thin cortical bone remaining [4]. On the other hand, pneumatic tract openings require closure, and more attention is paid to reducing postoperative complications [4]. Owing to poor preoperative assessment of the paranasal pneumatic system, there is a major increase in the risk of intraoperative accidents such as ICA or optic nerve injury [8].

Pneumatization variants in the LSW have previously been studied, as can be seen in Table 4. Although some data regarding the prevalence of pneumatization within the OS can be retrieved, it is mostly offered as circumstantial information in the analysis of the ACP air cells. Notions of OS dimensions and inclination are also present in the current literature but without mention of the pneumatic presence or its morphometric influence [6].

Additionally, to our knowledge, the patterns of origin for OS pneumatization were poorly evaluated, and there was no mention of ONCs as the source for it (Table 4). An important finding of the present study was the pneumatization of both the OS and AR from ONCs (11.62\%). This possibility constitutes the principal cause of risk for developing orbital complications, especially in patients with ethmoiditis $[9,10]$. Another incidental finding while conducting the present study was the possibility that an ONC could extend within the planum sphenoidale (Figure 5). This might explain why olfactory dysfunctions, such as anosmia or hyposmia, can occur in chronic rhinosinusitis [11,12].

Table 4. Literature review of the anterior clinoid process (ACP), optic strut (OS), and simultaneous OS and anterior root of the lesser sphenoidal wing (LSW) pneumatization.

\begin{tabular}{|c|c|c|c|c|c|}
\hline Study & $\begin{array}{l}\text { Materials and Planes } \\
\text { (A/C/Sag) }\end{array}$ & Lot $\mathrm{N}^{\circ}$ of Cases/Sides & $\begin{array}{c}\text { ACP } \\
\mathbf{N}^{\circ} \text { Patients/Sides } \\
\text { Prevalence }(\%)\end{array}$ & $\begin{array}{c}\text { OS }(\%) \text { and } \\
\text { Pattern }(\mathrm{S} / \mathrm{E} / \mathrm{S}+\mathrm{E} / \mathrm{O})\end{array}$ & $\begin{array}{c}\text { LSW }(\%) \text { and } \\
\text { Pattern }(\mathrm{S} / \mathrm{E} / \mathrm{S}+\mathrm{E} / \mathrm{O})\end{array}$ \\
\hline [13] & $\begin{array}{l}\text { MDCT } \\
\text { C }\end{array}$ & $300 / 600$ & $\begin{array}{l}44 / 55 \\
\text { N/A }\end{array}$ & $\begin{array}{c}74.5 \% \text { cases } \\
\text { S:37 } \\
\text { E: } 3 \\
\text { S+E: } 1 \\
\text { O: } 0\end{array}$ & $\begin{array}{c}\text { 10.9\% cases } \\
\text { S: } 3 \\
\text { E: } 0 \\
\text { S+E: } 3 \\
\text { O: } 0\end{array}$ \\
\hline$[14]$ & $\begin{array}{l}\text { CT } \\
\mathrm{A}\end{array}$ & $72 / 144$ & $\begin{array}{l}20 / 27 \\
13 / 7 \\
177 /-\end{array}$ & $\begin{array}{l}74.1 \% \text { sides } \\
\text { N/A }\end{array}$ & $\begin{array}{l}11.1 \% \text { sides } \\
\text { N/A }\end{array}$ \\
\hline [15] & $\begin{array}{l}\mathrm{CT} \\
\mathrm{A} / \mathrm{C}\end{array}$ & 499/998 (259 M) & $\begin{array}{c}\text { R: } 49.1 \% \\
\text { L: } 40.9 \% \\
\text { Bilat: } 37.2 \% \\
\quad 62 / 97\end{array}$ & $\begin{array}{l}\text { N/A } \\
\text { N/A }\end{array}$ & $\begin{array}{l}\text { N/A } \\
\text { N/A }\end{array}$ \\
\hline [4] & $\begin{array}{l}\mathrm{MDCT} \\
\mathrm{A} / \mathrm{C}\end{array}$ & $648 / 1296$ & $\begin{array}{c}\text { R: } 22.6 \% \\
\text { L: } 17.7 \% \\
\text { Bilat: } 59.7 \%\end{array}$ & $\begin{array}{l}38 \% \text { sides } \\
\text { N/A }\end{array}$ & $\begin{array}{l}17.7 \% \text { sides } \\
\text { N/A }\end{array}$ \\
\hline [16] & CT & 54/108 (24 M) & $\begin{array}{l}12 /- \\
\text { N/A }\end{array}$ & $\begin{array}{c}58.33 \% \text { cases } \\
\text { N/A }\end{array}$ & $\begin{array}{l}\text { N/A } \\
\text { N/A }\end{array}$ \\
\hline [17] & $\begin{array}{l}\text { CT/ } \\
\text { MRI } \\
\text { A/C }\end{array}$ & $\mathrm{N} / \mathrm{A}$ & $\begin{array}{l}\mathrm{N} / \mathrm{A} \\
\mathrm{N} / \mathrm{A}\end{array}$ & $\begin{array}{l}\mathrm{N} / \mathrm{A} \\
\mathrm{N} / \mathrm{A}\end{array}$ & $\begin{array}{l}\mathrm{N} / \mathrm{A} \\
\mathrm{N} / \mathrm{A}\end{array}$ \\
\hline [8] & $\begin{array}{l}\text { PNSCT } \\
\text { A/C }\end{array}$ & $\begin{array}{c}300 \\
(159 \mathrm{M})\end{array}$ & $\begin{array}{l}\text { N/A } \\
\text { N/A }\end{array}$ & $\begin{array}{l}\text { N/A } \\
\text { N/A }\end{array}$ & $\begin{array}{l}\text { N/A } \\
\text { N/A }\end{array}$ \\
\hline
\end{tabular}


Table 4. Cont.

\begin{tabular}{lccccc}
\hline Study & $\begin{array}{c}\text { Materials and Planes } \\
\text { (A/C/Sag) }\end{array}$ & Lot $\mathbf{N}^{\circ}$ of Cases/Sides & $\begin{array}{c}\text { ACP } \\
\mathbf{N}^{\circ} \text { Patients/Sides } \\
\text { Prevalence (\%) }\end{array}$ & $\begin{array}{c}\text { OS (\%) and } \\
\text { Pattern (S/E/S+E/O) }\end{array}$ & $\begin{array}{c}\text { LSW (\%) and } \\
\text { Pattern (S/E/S+E/O) }\end{array}$ \\
\hline & & & $53.12 \%$ & $26.87 \%$ \\
Present & CBCT & $80 / 160$ & $6 / 10$ & S:75 & E:32 \\
study & A/C/Sag & $(20 \mathrm{M})$ & $3 / 3$ & S+E: 0 & O: 1 \\
& & & S+E: 5 & O: 5 \\
\hline
\end{tabular}

S—sphenoid sinus; E—ethmoid sinus; O—Onodi cell; M-male; A—axial plane; C—coronal plane; Sag-sagittal plane; $\mathrm{R}-$ unilateral right side; L—unilateral left side; Bilat.—bilateral; CT—computed tomography; MDCT—multidetector CT, CBCT—cone beam CT; PNSCT—paranasal sinuses CT; MRI—magnetic resonance imaging.

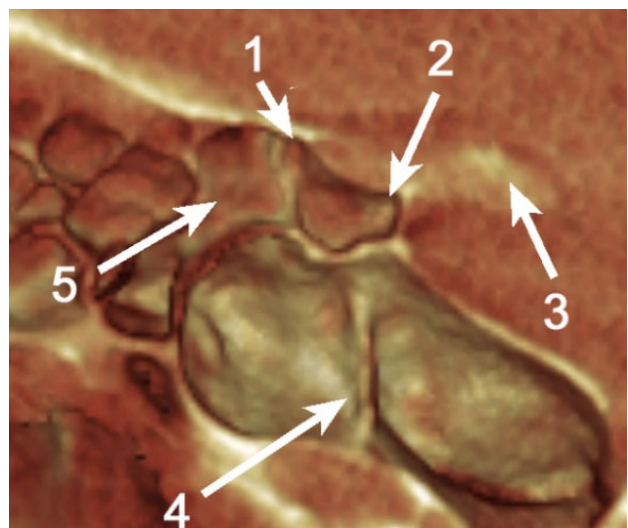

(a)

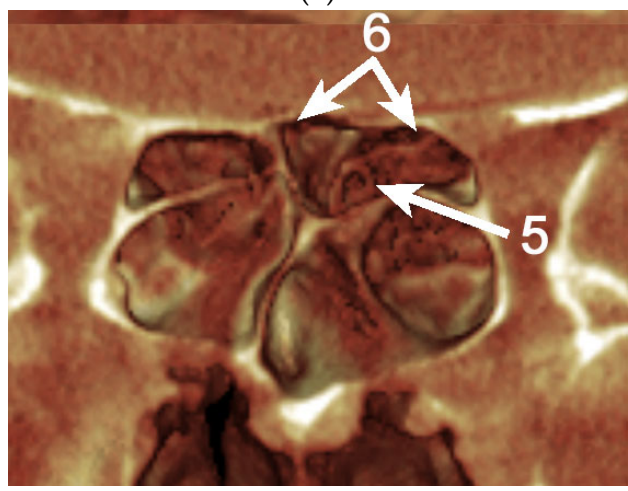

(c)

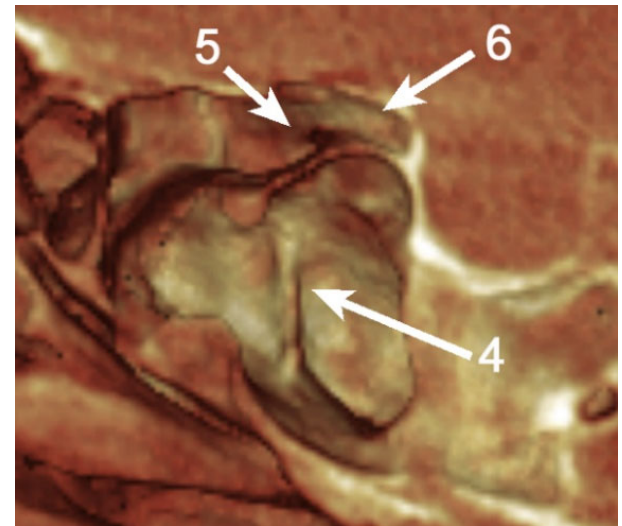

(b)

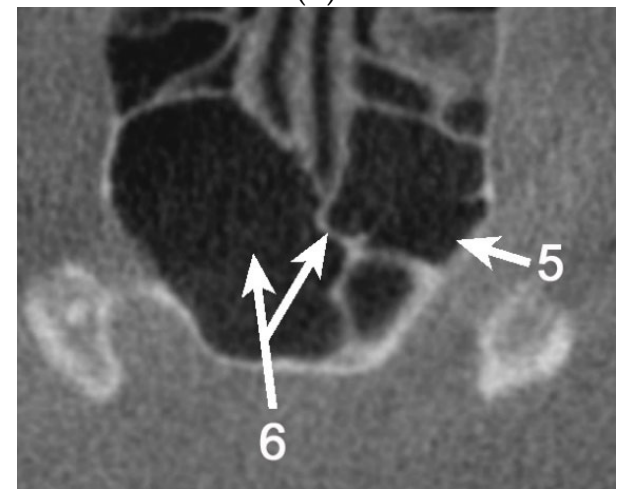

(d)

Figure 5. (a) Sagittal three-dimensional volume rendering (3DVR) of the anterior clinoid process (ACP) and paranasal air cells on the right side, which demonstrates a distinctive pneumatization of both the optic strut (OS) and anterior root (AR) of the lesser sphenoid wing, including the Onodi cell (ONC) as the origin of pneumatic cells. (b) Sagittal 3DVR of the ACP and paranasal air cells on the left side that demonstrates a pneumatization of the OS, including the ONC as the origin of pneumatic cells. (c) Coronal 3DVR of the ACP and paranasal air cells; the posterior view demonstrates a bilateral pneumatization of the planum sphenoidale (PS), with ONC as the origin. (d) Axial CBCT reconstruction at the level of the pneumatized OS. 1. Pneumatized AR; 2. Pneumatized OS; 3. ACP; 4. Sphenoid sinus; 5. ONC. 6. Pneumatized PS.

Cases of extended pneumatization within the LSW may determine the extension of inflammation and spread of infection in the ICA and the cavernous sinus $[2,18]$ or a decrease in visual acuity by developing orbital cellulitis $[9,10]$. Bilateral OS pneumatization and a high degree of communication between paranasal sinuses could entertain the possibility of neurovascular structures from both sides being affected simultaneously (Figure 6). 


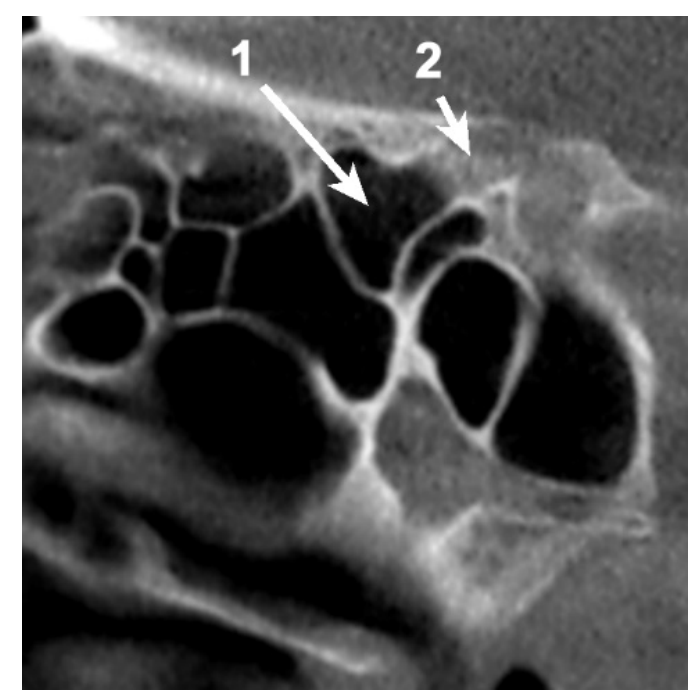

Figure 6. Sagittal CBCT reconstruction, demonstrating the topography of the left optic canal (OC) neighboring the extension of the right sphenoid sinus (false Onodi). 1. Extension of the right sphenoid sinus; 2. Left OC.

\section{Conclusions}

Sound knowledge of sphenoidal and ethmoidal pneumatization possibilities could reduce the rate of complications during different surgical procedures regarding the anterior clinoid process or the paraclinoid structures.

Preoperative risk assessment for anterior clinoidectomy should include verifying the presence of air cells within the OS and their origin, as well as the communicating nature of the LSW roots.

OS and ACP interventions could lead to postsurgical complications of both sphenoid and ethmoid sinuses due to the opening of a pneumatic tract of Onodi cell origin. Even more, given the interlaced aspect of some paranasal pneumatic systems, the risk of bilateral infection or sinusitis spread should be taken into account.

Additionally, the variations in morphometric features given by pneumatization tracts within the OS alter the usual intraoperative landmarks.

The CBCT can be a very useful tool in assessing the pneumatization patterns of the paranasal sinuses.

Author Contributions: Conceptualization, methodology resources and validation are credited to M.C.R. Formal analysis was attributed to C.T.S. Visualization, supervision, review and editing were accomplished by C.B. Data curation and original draft preparation were attributed to C.T.S. and C.B. Investigations have been made by M.C.R. and C.T.S. All authors have read and agreed to the published version of the manuscript.

Funding: This research received no external funding.

Institutional Review Board Statement: Not applicable.

Informed Consent Statement: Informed consent for use of CBCT DICOM files was obtained from all subjects involved in the study.

Conflicts of Interest: The authors declare no conflict of interest.

\section{References}

1. Taghipour, P.; Çakır, S.; Hamzaoğlu, V.; Özalp, H.; Kara, E.; Vayisoğlu, Y.; Dağtekin, O.; Dağtekin, A.; Bağdatoğlu, C.; Öztürk, A.H.; et al. Fetal Anatomy of the Optic Strut and Prechiasmatic Sulcus with a Clinical Perspective. World Neurosurg. 2020, 136, e625-e634. [CrossRef]

2. Gonzalez, L.F.; Walker, M.T.; Zabramski, J.M.; Partovi, S.; Wallace, R.C.; Spetzler, R.F. Distinction between paraclinoid and cavernous sinus aneurysms with computed tomographic angiography. Neurosurgery 2003, 52, 1131-1137, discussion 1138-1139. [PubMed] 
3. Cares, H.L.; Bakay, L. The clinical significance of the optic strut. J. Neurosurg. 1971, 34, 355-364. [CrossRef] [PubMed]

4. Abuzayed, B.; Tanriover, N.; Biceroglu, H.; Yuksel, O.; Tanriover, O.; Albayram, S.; Akar, Z. Pneumatization degree of the anterior clinoid process: A new classification. Neurosurg. Rev. 2010, 33, 367-373, discussion 374. [CrossRef] [PubMed]

5. Bichir, C.; Rusu, M.C.; Vrapciu, A.D.; Maru, N. The temporomandibular joint: Pneumatic temporal cells open into the articular and extradural spaces. Folia Morphol. 2019, 78, 630-636. [CrossRef] [PubMed]

6. Suprasanna, K.; Ravikiran, S.R.; Kumar, A.; Chavadi, C.; Pulastya, S. Optic Strut and Para-clinoid Region-Assessment by Multi-detector Computed Tomography with Multiplanar and 3 Dimensional Reconstructions. J. Clin. Diagn. Res. 2015, 9, TC06-TC09. [CrossRef] [PubMed]

7. Rusu, M.C.; Bichir, C.; Vrapciu, A.D. Transantral intraseptal sinuous canal. Folia Morphol. 2021. [CrossRef] [PubMed]

8. Asal, N.; Bayar Muluk, N.; Inal, M.; Sahan, M.H.; Dogan, A.; Arikan, O.K. Carotid canal and optic canal at sphenoid sinus. Neurosurg. Rev. 2019, 42, 519-529. [CrossRef] [PubMed]

9. Schramm, V.L., Jr.; Curtin, H.D.; Kennerdell, J.S. Evaluation of orbital cellulitis and results of treatment. Laryngoscope 1982, 92, 732-738. [CrossRef] [PubMed]

10. Gutowski, W.M.; Mulbury, P.E.; Hengerer, A.S.; Kido, D.K. The role of C.T. scans in managing the orbital complications of ethmoiditis. Int. J. Pediatr. Otorhinolaryngol. 1988, 15, 117-128. [CrossRef]

11. Neuland, C.; Bitter, T.; Marschner, H.; Gudziol, H.; Guntinas-Lichius, O. Health-related and specific olfaction-related quality of life in patients with chronic functional anosmia or severe hyposmia. Laryngoscope 2011, 121, 867-872. [CrossRef] [PubMed]

12. Chiang, G.S.; Goh, L.G. Olfactory groove and planum sphenoidale meningioma: Dementia masquerade. Can. Fam. Physician 2017, 63, 288-291. [PubMed]

13. Mikami, T.; Minamida, Y.; Koyanagi, I.; Baba, T.; Houkin, K. Anatomical variations in pneumatization of the anterior clinoid process. J. Neurosurg. 2007, 106, 170-174. [CrossRef] [PubMed]

14. Ota, N.; Tanikawa, R.; Miyazaki, T.; Miyata, S.; Oda, J.; Noda, K.; Tsuboi, T.; Takeda, R.; Kamiyama, H.; Tokuda, S. Surgical microanatomy of the anterior clinoid process for paraclinoid aneurysm surgery and efficient modification of extradural anterior clinoidectomy. World Neurosurg. 2015, 83, 635-643. [CrossRef] [PubMed]

15. Burulday, V.; Muluk, N.B.; Akgul, M.H.; Kaya, A.; Ogden, M. Presence and types of anterior clinoid process pneumatization, evaluated by Multidetector Computerized Tomography. Clin. Invest. Med. 2016, 39, E105-E110. [CrossRef] [PubMed]

16. Suprasanna, K.; Kumar, A. Surgically Relevant Bony Anatomical Variations in Paraclinoid Aneurysms-Three-Dimensional Multi-Detector Row Computed Tomography-Based Study. J. Neurosci. Rural Pract. 2017, 8, 330-334. [CrossRef] [PubMed]

17. Kantarci, M.; Karasen, R.M.; Alper, F.; Onbas, O.; Okur, A.; Karaman, A. Remarkable anatomic variations in paranasal sinus region and their clinical importance. Eur. J. Radiol. 2004, 50, 296-302. [CrossRef]

18. Lee, H.Y.; Chung, I.H.; Choi, B.Y.; Lee, K.S. Anterior clinoid process and optic strut in Koreans. Yonsei Med. J. 1997, 38, 151-154. [CrossRef] [PubMed] 